\title{
RELATO DE CASO: ACNE FULMINANS E ISOTRETINOÍNA
}

\author{
CASE REPORT: ACNE FULMINANS AND ISOTRETINOIN
}

\author{
Gustavo Schott Peixoto ${ }^{1}$, Mariana Canova Da Silveira ${ }^{2 *}$, Roberta Ayres Ferreira \\ Volpe ${ }^{2}$.
}

${ }^{1}$ Hospital Universitário Regional de Maringá, Maringá, PR, Brasil.

${ }^{2}$ Universidade Estadual de Maringá, Maringá, PR, Brasil.

*ra98382@uem.br

\section{RESUMO}

Masculino, 15 anos, com acne fulminans evoluída de acne vulgar após 2 meses de uso de isotretinoína. Mãe é antecedente familiar de acne grave. Na consulta de entrada: febril $\left(39^{\circ} \mathrm{C}\right.$ ), prostrado e emagrecido, com relato de perda de $5 \mathrm{Kg}$ em 2 meses e queixas de cefaleia e mialgia. Nega medicações contínuas, tabagismo, etilismo e uso de ilícitos. A mãe do paciente relata que o período da manifestação clínica coincide com sua fase de divórcio. Ao exame dermatológico: múltiplas lesões nodulares de até $3,5 \mathrm{~cm}$ de diâmetro, dolorosas à palpação, com drenagem espontânea de secreção serossanguinolenta e exulcerações recobertas por crostas, em face, tórax e dorso. Laboratoriais: discreta anemia microcítica hipocrômica com anisocitose e leucocitose sem desvio. Sem necessidade de internação, o tratamento foi dado com uso oral de prednisona $30 \mathrm{mg}$, sulfametoxazol-trimetoprim $800 \mathrm{mg} / 160 \mathrm{mg}$ por 10 dias, mantendo-se isotretinoína $20 \mathrm{mg}$, e uso tópico de colagenase 0,6U/g. Ademais, iniciou-se reeducação alimentar e avaliação nutricional seriada. $O$ paciente evoluiu com melhora das queixas álgicas, dos sinais e sintomas sistêmicos, e com redução significativa das lesões cutâneas, sobre as quais se formou tecido de granulação coberto por crostas hemorrágicas, sem formação de abscessos. Após 4 meses, ganho de $10 \mathrm{Kg}$ e cicatrização extensa das feridas, resultado satisfatório do tratamento. O relato configura um caso típico de acne fulminans, afecção dermatológica rara e grave, com poucos registros na literatura. Embora sua etiopatogenia permaneça obscura, são vários os fatores apontados como desencadeantes. Níveis elevados de testosterona, por exemplo, explicam por que adolescentes masculinos são mais acometidos. Tem-se a terapêutica com isotretinoína como condição instigadora, por induzir fragilidade aos folículos pilossebáceos, promovendo quimiotaxia neutrofílica e resposta imunológica acentuada frente à exposição cutânea a antígenos externos. Também, associase à manifestação psicossomática de estresse, já que mudanças psiconeuroimunológicas podem ser expressas pela pele, a qual enuncia ou exacerba lesões. Ainda não há padronização do tratamento, sendo realizado, em geral, como neste caso, com prednisona, isotretinoína e antibióticos para possíveis infecções secundárias. Ainda que este paciente tenha recusado, salienta-se a influência do estresse sobre a doença, sendo psicoterapia um bom recurso. E, enfatiza-se a relevância do acompanhamento nutricional, que contribuiu com o bom progresso do caso. Por fim, mesmo com a evolução satisfatória, as lesões deixaram amplas cicatrizes, demonstrando a importância 
de diagnóstico e tratamento precoces, que podem diminuir substancialmente a morbidade da acne fulminans.

Palavras-chave: Acne. Fulminans. Isotretinoína. Medicina. Psicossomática. 